\title{
Taking Sustainability from Theory to Practice
}

\section{Andy Hargreaves and Dean Fink}

Sustainable leadership and improvement are more than matters of mere endurance, of making things last. We define sustainable leadership, in line with the environmental field, in the following way:

Sustainable leadership matters, spreads and lasts. It is a shared responsibility, that does not unduly deplete human or financial resources, and that cares for and avoids exerting negative damage on the surrounding educational and community environment. Sustainable leadership has an activist engagement with the forces that affect it, and builds an educational environment of organizational diversity that promotes cross-fertilization of good ideas and successful practices in communities of shared learning and development.

This definition suggests seven principles of sustainable leadership:

1. Sustainable leadership creates and preserves sustaining learning.

2. Sustainable leadership secures success over time.

3. Sustainable leadership sustains the leadership of others.

4. Sustainable leadership addresses issues of social justice.

5. Sustainable leadership develops rather than depletes human and material resources.

6. Sustainable leadership develops environmental diversity and capacity.

7. Sustainable leadership undertakes activist engagement with the environment

We live in an educational world of relentless reform and ceaseless change (Hargreaves, 2003). The achievement and equity goals of reform are admirable; yet the processes for reaching them are frequently flawed and almost always frustrating. If the first challenge of change these days, is to ensure that it is desirable, and the second challenge is to make it doable, then the biggest challenge of all is to make it durable and sustainable.

Yet what does sustainability mean? Lester Brown, founder of the World Watch Institute, defined a sustainable society as one that is able to satisfy its needs without diminishing the opportunities of future generations to meet 
theirs. In education, Fullan (2005) defines educational sustainability as «the capacity of a system to engage in the complexities of continuous improvement consistent with deep values of human purpose.» Our own definition builds on the one we used when we started our work on sustainability some years ago.

Sustainable educational leadership and improvement preserves and develops deep learning for all that spreads and lasts, in ways that do no harm to and indeed create positive benefit for others around us, now and in the future. (Hargreaves \& Fink, 2003).

Drawing on the environmental and corporate literature as well as our Spencer Foundation study of Change Over Time in eight US and Canadian secondary schools over 30 years through the eyes of the teachers and leaders who worked there in the 1970s, 80s, and 90s (Hargreaves \& Goodson, 2006), we have created an explanatory framework of seven principles of sustainable leadership.

\section{Depth}

Sustainable leadership matters. We must preserve, protect and promote in education what is itself sustaining as an enrichment of life: the fundamental moral purpose of deep and broad learning (rather than superficially tested and narrowly defined achievement) for all in commitments to and relationships of abiding care for others.

\section{Length}

Sustainable leadership lasts. It preserves and advances the most valuable aspects of life over time, year upon year, from one leader to the next. The challenges of leadership succession, of leading across and beyond individual leaders

over time, are at the very heart of sustainable leadership and educational change.

\section{Breadth}

Sustainable leadership spreads. In a complex world, no one leader, institution or nation can control everything without help: sustainable leadership is distributed leadership.

\section{Justice}

Sustainable leadership does no harm to and actively improves the surrounding environment. It does not raid the best resources of outstanding students and teachers from neighboring institutions. It does not prosper at other schools' expense. It does no harm to and actively finds ways to share knowledge and resources with neighboring schools and the local community. Sustainable leadership is not self-centered; it is socially just.

\section{Diversity}

Sustainable leadership promotes cohesive diversity. Strong ecosystems are biodiverse ones. Strong organizations too, promote diversity and avoid standardization. Sustainable leadership fosters and learns from diversity in teaching and learning and moves things forward by creating cohesion and networking among its richly varying components. 


\section{Resourcefulness}

Sustainable leadership develops and does not deplete material and human resources. Sustainable leadership recognizes and rewards the organization's leadership talent in earlier rather than later career. It does not drain its leaders dry through innovation overload or unrealistic timelines for change. Sustainable leadership is prudent and resourceful leadership that wastes neither its money nor its people.

\section{Conservation}

Sustainable leadership honors and learns from the best of the past to create an even better future. Most change theory and change practice has only a forward arrow. It is change without a past or a memory. Sustainable leadership revisits and revives organizational memories and honors the wisdom of their bearers as

a way to learn from, preserve, and then move beyond the best of the past.

\section{Action Principles}

For sustainability to be practical, however, it is important to grasp not just what sustainability looks like, but also how to achieve it. To this end, we now outline five action principles for achieving sustainability in practice.

- activism

- vigilance

- patience

- transparency

- design

\section{Activism}

Sustainable leadership is activist; it engages assertively with its environment. In the face of standardized reform, innovative schools tend to lose a lot of their edge. But the most resilient schools don't just react to external and unwanted pressures; they engage assertively with their environment. Durant School in New York State provides a compelling example of sustainability in action.

The founding principal of Durant believed that the school's original vision of fostering independent learning in real-life settings would survive only if teachers, students, and parents shared that vision. Indeed, because of his many other admirable and ethical qualities, teachers were prepared to cover for his more routine administrative shortcomings. Long after the principal's retirement, the teachers and other members of the school community continued to resist the standardizing policies of the district and state, holding fast to their founding vision by seeking waivers for their distinctive program.

In the past few years, the school's courageous new principal has activated his personal and professional networks and forged strategic alliances with the community in a tireless campaign to preserve the school's mission. Durant's story 
shows that, especially in an unhelpful reform environment, sustainable leadership is necessarily also activist leadership.

\section{Vigilance}

Sustainable leadership is vigilant: it monitors the environment to check it is staying healthy and not beginning to decline. In any environment, we need data, instruments, measurements to check if things are worsening, before it's too late, and also to ensure they really are improving when we try to make them better.

Schools and school systems can become toxic environments of wasted and seemingly disposable human potential (Hargreaves et al., 2006). Sometimes the evidence is there for all to see - in crime, disorder, absenteeism, lack of learning and loss of hope. But often the effects are more subtle and, as conditions deteriorate, people might not only be unaware of the deterioration but many may even find it deceptively more comfortable. Results might improve, but only because of a few high achievers; teachers might be coasting comfortably along, but motivation to stay in teaching or take up leadership roles might start to decline.

Noumea Primary School is part of a post World-War II, planned community near Sydney, Australia (Lewis \& Caldwell, 2005). Over time, the community has deteriorated into a lower class, multi-ethnic neighbourhood of intergenerational unemployment and endemic poverty. In spite of its challenging community and a student turnover rate of over 40 per cent, this school of 530 students has won national awards, and international recognition for its high standards, innovative approaches to literacy and mathematics, and ingenious uses of technology.

Principal Jenny Lewis, the school's principal from 1994 to 2004, handled her youthful staff and demanding community with skill, tenacity and charm. Over her ten year tenure, she created a professional learning community which ensured that teachers had the time, resources and encouragement to develop, share, and use their knowledge in support of teaching, learning and caring for every child in the school.

Lewis and her colleagues promoted community learning through on-going visioning activities, development of a shared language, and collection and analysis of information about the school and its mission. Through serious self-reflection, and with more-than-satisfactory results as their ally, Noumea's staff decided that state-sponsored standardized tests interfered with their focus on student outcomes. By mobilizing community support and after some expert politicking with the state government, Lewis and her colleagues received permission to use daily teacher assessments of student learning and achievement to inform lessons and communicate with parents. Grade-related teacher teams monitored this process and results of these data-driven sectional meetings were shared at monthly staff meetings to determine trends and patterns for the entire school and to strive for continuous improvement.

Noumea has created an evidence-informed environment that can challenge (or confirm) intuition in a practical way. Together, these integrated efforts have 
lifted the school from being "at significant risk" to ranking among the top 25 schools in New South Wales.

\section{Patience}

Sustainable leadership is patient: it defers gratification instead of seeking instant results. Sustainable leadership is patient and persevering. It invests urgently in improvement but does not expect or insist upon instant success, and is therefore dependent on habits of mind that are not impatient for rapid results.

Yet we no longer live in a world that values patience and permanence. Ours is, instead, a disposable society, a society of wanton waste - of things that have planned obsolescence rather than being built to last, in which policies pander to opinion polls and appearances - driven by the need for instant impact, positive «spin», and quick-fix results.

In 2001, the Canadian province of Ontario introduced a high stakes literacy test in Grade 10. It was applied to virtually all students who were required to pass in order to graduate. High stakes, high pressure! Ivor Megson, the new principal at Talisman Park secondary school was dedicated to his work as a leader but did not like to rock the boat too much.

With his staff, Ivor figured out the most minimal and least disruptive school response to the Grade 10 test: one that would produce the best results with the least amount of effort. Quickly, Ivor and his staff began identifying a group of students who, pre-tests indicated, would fall just below the pass mark. The school then coached or "prepped» these students intensively in literacy learning, so they would perform acceptably when the real test came around. Technically, the strategy worked. The school's results looked good. But teachers' energies are finite, and as staff concentrated on those students near the cut-off point, the ones who really needed help with literacy and had little chance of making the pass threshold, were cast by the wayside. In Talisman Park, authentic literacy, learning for all, and especially for the most needy, was sacrificed to appearances and results.

Charmaine Watson was the principal of Wayvern High school, just up the road from Talisman Park. Wayvern was a culturally and ethnically diverse school and had a high number of students for whom English was their second language. Wayvern had a lot to lose on the literacy test. Yet Charmaine's school made literacy, not the literacy test, one of their key improvement goals. Charmaine engaged her staff in inquiry about how to improve literacy so it would benefit all students in the long term, instead of focusing on how to manipulate the shortterm scores on the test, and undertook various initiatives aiming at the improvement of the literacy skills of her students. The immediate test results were not spectacular (as is usual with more sustainable change), but together, the staff and parents were confident that long-term improvement mattered the most. 


\section{Transparency}

Sustainable leadership is transparent; it is always open to scrutiny and inspection. Martha Stewart, Nick Leeson, Nortel, Enron and World Com: the new millennium marked a collapse of trust in an opaque and unaccountable world of business and finance that served itself at the expense of its clients and that duped the public into believing economic progress had no limit and the party would never end.

Corporate meltdown and government «spin» have made people increasingly suspicious about the organizations that affect their lives. With growing access to and sophistication in using modern communication technology, determined and dedicated citizens can now act on these suspicions and prize information out of institutions - forcing them to be more open in their dealings.

The result has been a move towards greater openness of information and communication. Sometimes this is a reluctant and grudging accommodation to unrelenting external pressure. But increasingly, it is also a result of proactive efforts by leading companies to rebuild trust with clients and communities by sharing data openly, actively seeking feedback and being honest about mistakes. Transparency is in: opacity is out.

Many beacon or model schools prosper by stealing the best teachers and students from other schools. Blue Mountain in Ontario, Canada provides an inspiring example of a school that stripping its neighbours by being totally transparent.

The school opened in 1994 and by 2000 enrolled 1250 students. Established with a charismatic principal and carefully selected staff, many of whom had former connections with him, and with the advantage of a full year's advanced planning, the school established great technological, structural and curriculum innovations compared to the standard "grammar of secondary schooling» (Tyack \& Tobin, 1994).

The school is self-consciously a learning organization, and more recently a professional learning community. The idea of organizational learning and systems thinking permeated almost everything the founding principal did. In the early years, the principal worked with teachers and other staff to build a vision of a student-cantered community. As one teacher commented, "I'd never been in a place where the priority was so much the student; and for me, that's it - all that matters is the student.» Virtually all of the highly dedicated and enthusiastic staff participated in personal and professional learning outside school as well as within it.

Blue Mountain School shared data openly with parents - including data that might arouse as well as allay anxiety. Yet data at Blue Mountain were regarded not as ways to fabricate favorable impressions, or as means to pass conclusive judgments about their failure or success. Instead, data and evidence provided opportunities for inquiry and conversation within the school's wider learning community. 
Sustainable leadership reaches out to communities. It invites direct engagement; two-way, jargon-free, communication; and meaningful participation by students, parents and communities in the life of the school. Sustainable leadership is honest and forthright about failures as well as successes. Because it aspires to greater integrity, sustainable leadership also advocates for and has no fear of increased transparency. Sustainable leadership wants to be seen in its true colors, not viewed through rose-colored glasses.

\section{Design}

Sustainable leadership is designer-made: it creates systems that are personalized for people's use and compatible with human capacity. All systems in nature are emergent and are the product of evolutionary adaptation. As humans, we are capable of designing even more complex structures than those of nature because of our abilities in language and conceptualization. But our efforts often disappoint. They impose outdated mechanical models that try to master and control nature, rather than ecological or even designer models which work more effectively and in tune with diverse people and their local environments.

At Stewart Heights, first-time principal, Jerry West was rapidly promoted in mid-term to replace Bill Andrews. Facing a school that was experiencing its third principal in four-and-a-half years, and an escalating government reform agenda, West had no time to establish himself as a leader. His response was to make no changes in his first semester and build relationships one at a time, but this strategy led to inertia and drifting. Departmental power structures reasserted themselves to fill the void, and staff on the School Climate committee set about creating stricter codes for student behaviour rather than continuing Andrews' commitment to whole school change.

As staff said of West and his newly appointed administrative team: «nice people can't cope!» Rapid rotation of leadership, poor succession planning and the onset of an overwhelming reform agenda, undermined two years of considerable improvement. After just three years, West himself was moved on to another school. Three days into his new principalship, he was taken to hospital with a suspected mental breakdown!

Sustainable leadership devises structures that take into account what Kim Vicente calls the «human factor» (Vincente, 2003). Vicente, an engineer at the University of Toronto, argues that technology should be tailored to suit people and their environment rather than expecting people to adapt to the technology. Vicente describes how we have created a mechanistic world that is capable of producing very sophisticated technology, alongside a human and natural world that constantly struggles to adapt and adjust. This is a classic case of Homer-Dixon's ingenuity gap - of human design not having the capacity to keep up with or resolve the problems it has created (Homer-Dixon, 2000). 


\section{Sustainability in Action}

By designing policies that build on the seven dimensions of sustainability (depth. length, breadth, diversity, justice, resourcefulness and conservation) and crafting implementation plans around our five action principles, educational jurisdictions can effect the changes required to enhance deep and lasting learning for all students. The Canadian province of Alberta's approach to educational change provides a useful summary example of it.

The Alberta Government and the province's Teachers' Union were at a standoff regarding the Government's proposal to raise student performance. A new Minister, along with a teacher's union executive that had always taken a forwardlooking stand on improvement through professional development decided to approach the problem another way. In 1999, they jointly launched the Alberta School Improvement Initiative (AISI). The program addressed issues of diversity and flexibility by «fostering initiatives that reflect the unique needs and circumstances of each school authority» (Alberta Learning, 2004). An injection of $\$ 68 \mathrm{~m}$ of resources was targeted annually for local improvement projects.

The initiative does not operate in a climate of imposed and accelerated government targets. Instead, schools establish their own targets, in terms of impact on student learning and satisfaction levels. Impressively, in this culture of shared targets, $90 \%$ of schools exceeded their baseline on the majority of measures every year. Over just three years, almost half the project schools improved student learning and 57\% improved levels of student, teacher and parent satisfaction. And this is only the start

AISI has a focus on learning, on building strong professional learning communities, in ways that respond to and connect, in an ecological way, the diverse paths to improvement across the province.

In Alberta, the teachers' union and the government actively engaged in politically risky negotiations to create a system that has not only met the government's need for demonstrable improvement in student achievement but actively and in many places enthusiastically enrolled teachers and other educational partners such as parents and institutions of higher learning in the pursuit of the same goal. By $p a-$ tiently working through an approach to reform that allows schools and school systems to negotiate, goals, targets, and most importantly, timelines that connect to the realities of each school and district in the province, the participants created a synergy among the key players that is quite rare in many western countries.

All results are open and transparent to both the people inside the system as well as the public at large. The vigilance of the government and each school district as well as their collective emphasis on assessment literacy have allowed individuals and schools to continuously review their progress towards the overall goal of enhanced student achievement. This change design not only takes into account the Alberta government's need for accountability to its citizens and the 
uniqueness of local communities but also the «human factor» - the real work and lives of teachers and school leaders.

\section{Conclusion}

Ardent environmentalists have defined the leading edge of sustainability. More and more businesses are combining money with morality, and are following close behind. After years of resource-depleting standardization in education, many governments such as the Alberta case we described are increasingly seeking more prudent and also ingenious ways to secure lasting and widespread educational improvement for all their students. It is time for other governments to follow their lead and for schools to show that greater trust in and support for their own improvement abilities will not lead to loss of energy, urgency or effectiveness. We cannot afford to waste the time and energy of our teachers and our leaders any longer. But most of all, we can tolerate no more wasted lives among our children. Both these things are connected. We have an opportunity to leave behind the overconfident mechanical age of endless waste and enter a more sustainable era of hopeful renewal. It is an opportunity that must be seized. The lives of our children and the legacy we leave them depend on it.

\section{References}

Alberta Learning. (2004). Improving student learning: Alberta initiative for school improvement. Edmunton, Alberta.

Fullan, M. (2005). Leadership and Sustainability. System thinkers in action, San Francisco: Jossey-Bass., ix.

Hargreaves, A. (2003). Teaching and Learning in the Knowledge Society: Education in the age of insecurity. New York: Teachers' College Press.

Hargreaves, A., \& Fink, D. (2003). Sustaining leadership. Phi Delta Kappan, 84 (9), 693-700.

Hargreaves, A., \& Goodson, I. (2006). Educational change over time? The sustainability and non-sustainability of three decades of secondary school change and continuity, Educational Administration Quarterly. 42 (1).

Homer-Dixon, T. (2000). The ingenuity gap: Can we solve the problems of the future? New York: Alfred A. Knopf.

Lewis, J., \& Caldwell, B. (2005). Exidence based leadership. The Educational Forum, 69 (2), 182-191.

Tyack, D., \& Tobin, W. (1994). The grammar of schooling: Why has it been so hard to change? American Educational Research Journal, 31 (3), 453-480.

Vincente, K. (2003). The Human Factor: Revolutionizing the way people live with technology. Toronto: Alfred A. Knopf Canada.

Keywords: School, Education, Quality, Improvement, Sustainability, Educational leadership, Activism, Delayed gratification, Transparency, Systems design 


\section{Nachhaltigkeit zwischen Theorie und Praxis}

\section{Zusammenfassung}

Nachhaltige Führung und Verbesserung sind mehr als eine Frage der Geduld, um etwas zu bewahren. Wir definieren nachhaltige Führung - in Verzahnung mit der Umwelt - wie folgt: Nachhaltige Führung ist wichtig, breitet sich aus, überdauert. Sie bezeichnet eine geteilte Verantwortung, wonach kein übermässiger Raubbau an menschlichen und finanziellen Ressourcen betrieben wird. Sie kümmert sich um die Erziehungsumwelt und die Gemeinde bzw. vermeidet negative Schädigungen. Nachhaltige Führung impliziert ein aktives Engagement mit den Kräften, welche sie steuern und schafft ein organisatorisch vielfältiges Erziehungsumfeld, welches Anregung von guten Ideen sowie erfolgreiche Praktiken in Lern- und Entwicklungsgruppen unterstützt.

Diese Definition schlägt sieben Prinzipien nachhaltiger Führung vor:

1. Nachhaltige Führung schafft und bewahrt nachhaltiges Lernen.

2. Nachhaltige Führung sichert Erfolg über die Zeit.

3. Nachhaltige Führung stützt die Führung von anderen.

4. Nachhaltige Führung richtet sich auf Fragen der sozialen Gerechtigkeit.

5. Nachhaltige Führung fördert eher menschliche und materielle Ressourcen statt sie abzubauen.

6. Nachhaltige Führung entwickelt vielfältige und leistungsbejahende Umwelten.

7. Nachhaltige Führung übernimmt ein aktives Engagement gegenüber der Umwelt.

Schlagworte: Schule, Erziehung, Qualität, Entwicklung, Nachhaltigkeit, Schulführung, Aktivismus, verzögerte Belohnung, Transparenz, Systemdesign

\section{Leadership durable: de la théorie à la pratique}

Résumé

Un leadership et une amélioration durable ne dépendent pas uniquement d'une question de résistance ou d'une capacité de faire durer les choses. Nous définons le leadership durable, en prolongeant les réflexions environnementales, de la façon suivante :

Le leadership durable intéresse, s'étaye et dure. Il s'agit d'une responsabilité partagée, qui n'entame pas de façon injustifiquée les ressources humaines et financières et qui cherche à éviter de commettre des dégâts dans l'environnement éducatif et communautaire circonstant. Le leadership durable prend un engagement avec les forces qui touchent cet environnement e construit un contexte éducatif basé sur la diversité organisatrice qui soutient l'inter-fertilisation des bonnes idées e des pratiques de succès dans les communauté qui partagent le même apprentissage et le même développement. 
Cette définition suggère sept principes du leadership durable

1. Le leadership durable crée et maintient un apprentissage durable

2. Le leadership durable assure le succès dans le temps

3. Le leadership durable soutient le leadership des autres

4. Le leadership durable aborde questions de justice sociale

5. Le leadership durable développe au lieu de entamer les ressources humaines et matérielles.

6. Le leadership durable développe la diversité e la capacité environnementales

7. Le leadership durable entreprend des initiatives engagées sur le front de l'environnement.

Mots clés: École, éducation, qualité, leadership scolaire, activisme, reconnaissance à posteriori, transparence, design systémique

\section{Leadership sostenibile: dalla teoria alla pratica}

\section{Riassunto}

Una leadership e un miglioramento sostenibili non dipendono unicamente da una questione di resistenza, o di capacità a far durare le cose. Definiamo una leadership sostenibile, prolungando le riflessioni in ambito ambientale, nei termini seguenti:

La leadership sostenibile interessa, si diffonde e dura. È una responsabilità condivisa, che non intacca ingiustificatamente le risorse umane e finanziarie e che si preoccupa di evitare di provocare danni nel contesto educativo e comunitario circostante. La leadership sostenibile manifesta un impegno con quelle forze che interessano tale contesto e costruisce un ambiente educativo basato su una diversità organizzativa che promuove l'inter-fertilizzazione delle buone idee e delle pratiche di successo nelle comunità che condividono l'apprendimento e lo sviluppo.

Questa definizione suggerisce sette principi della leadership sostenibile:

1. La leadership sostenibile crea e conserva un apprendimento sostenibile.

2. La leadership sostenibile assicura il successo nel tempo.

3. La leadership sostenibile sostiene la leadership degli altri.

4. la leadership sostenibile affronta questioni di giustizia sociale.

5. La leadership sostenibile sviluppa invece di intaccare le risorse umane e materiali.

6. La leadership sostenibile sviluppa la diversità e la capacità ambientale.

7. La leadership sostenibile intraprende iniziative impegnate sul fronte dell'ambiente.

Parole chiave : scuola, educazione, qualità, leadership scolastica, attivismo, gratificazione posticipata, trasparenza, design sistemico 
